\title{
Corrosion Behaviour of Type 316L Stainless Steel in Hot Caustic Aqueous Environments
}

\author{
Raul Davalos Monteiro $^{1}\left[\right.$ ] Jan van de Wetering ${ }^{2} \cdot$ Benjamin Krawczyk $^{1} \cdot$ Dirk L. Engelberg $^{1}$ (i)
}

Received: 28 January 2019 / Accepted: 28 July 2019 / Published online: 20 October 2019

(c) The Author(s) 2019

\begin{abstract}
The corrosion behaviour of type 316L stainless steel in aqueous $30-50 \mathrm{wt} \% . \mathrm{NaOH}$ at temperatures up to $90{ }^{\circ} \mathrm{C}$ has been elucidated. Exposure to room temperature environment showed parabolic weight loss behaviour, with corrosion rates of up to $0.4 \mathrm{~mm} /$ year. Higher $\mathrm{NaOH}$ concentrations and exposure temperatures resulted in a reduced stability of the electrochemical passivity domain, associated with higher corrosion rates. Exposure to de-aerated $50 \mathrm{wt} \%$. $\mathrm{NaOH}$ presented corrosion rates of up to $0.5 \mathrm{~mm} / \mathrm{year}$ at open circuit potential, with maximum corrosion rates under polarisation of up to $\approx 18 \mathrm{~mm} / \mathrm{year}$. The formation of a dark iron-oxy-hydroxide and nickel-oxide was observed, with exposure to temperatures in excess of $50{ }^{\circ} \mathrm{C}$. The behaviour of type 316L stainless steel in hot caustic environment is compared to types 204, 304, 2205 stainless steel, and nickel alloy 200.
\end{abstract}

Keywords Stainless steel $\cdot \mathrm{NaOH} \cdot$ Corrosion rates $\cdot$ Potentio-dynamic polarisation $\cdot$ Weight loss $\cdot$ Passivation

\section{Introduction}

The corrosion of stainless steel in hot caustic environment has been the subject of a number of investigations, typically with a focus on Kraft pulping liquors [1-11]. The material performance in these environments is governed by the stability of the passive surface film, which develops as a function of alloy microstructure, chemical composition, and associated environmental interactions. Austenitic stainless steels generally show high corrosion rates when exposed to concentrated, deaerated alkaline aqueous environment at temperatures above $60{ }^{\circ} \mathrm{C}$, with typical corrosion rates of $0.05-2 \mathrm{~mm} /$ year. Very dilute caustic solutions show reduced corrosion susceptibility, for example, with exposure to mildly caustic environment

Raul Davalos Monteiro

raul.davalosmonteiro@postgrad.manchester.ac.uk

Jan van de Wetering

jan.vandewetering@nouryon.com

Dirk L. Engelberg

dirk.engelberg@manchester.ac.uk

1 Corrosion and Protection Centre, School of Materials, The University of Manchester, Manchester M13 9PL, United Kingdom

2 Materials Technology- Asset Management, Nouryon Industrial Chemicals, P.O. Box 9300, Arnhem 6800 SB, The Netherlands up to $\mathrm{pH} 12$, resulting in corrosion rates of $0.01 \mathrm{~mm} / \mathrm{year}$ [12-14]. The latter investigation also concluded that temperature is key for understanding material behaviour in these environments, directly affecting corrosion rates of stainless steel in $\mathrm{NaOH}$ containing environment [6, 7].

In $\mathrm{NaOH}$ environment at room temperature, rates as low as a few $\mu \mathrm{m} /$ year have been reported [6,15-22]. Based on the Pourbaix diagrams of Iron, Chromium and Nickel, the possibility of forming a passive film with exposure to caustic $\mathrm{pH}$ supports the argument of using stainless steel in these media. A summary of the corrosion behaviour of stainless steels with exposure to different caustic environments is provided in [12].

The aim of this paper is to provide a comprehensive overview of the corrosion performance of type $316 \mathrm{~L}$ in hot caustic aqueous environments. The project was centered on identifying alloy composition and environment-related parameters, including temperature, de-aeration, and $\mathrm{NaOH}$ concentration, to better understand the passivation behavior of stainless steels microstructure.

\section{Materials and Methods}

A mill annealed type $316 \mathrm{~L}$ austenitic stainless steel sheet with a chemical composition of (wt\%) $16.7 \mathrm{Cr}, 10.1 \mathrm{Ni}, 2.04 \mathrm{Mo}$, $0.019 \mathrm{C}, 0.049 \mathrm{~N}$ was used in this study. The sheets had dimensions of $1000 \mathrm{~mm} \times 1000 \mathrm{~mm} \times 1 \mathrm{~mm}(\mathrm{~L} \times \mathrm{W} \times \mathrm{T})$ from which 
$20 \mathrm{~mm} \times 20 \mathrm{~mm} \times 1 \mathrm{~mm}(\mathrm{~L} \times \mathrm{W} \times \mathrm{T})$ strips were prepared. The strips were spot welded to a copper wire, with all connections and wires then covered in plastic tubing. The samples were mounted in Araldite, with one side ground to 2400 grit, followed by polishing to a $1 / 4$ micron diamond paste finish.

Electro-chemical polarisation tests were undertaken at room temperature, $50{ }^{\circ} \mathrm{C}, 70{ }^{\circ} \mathrm{C}$ and $90{ }^{\circ} \mathrm{C}$ in $30 \mathrm{wt} \%$, $40 \mathrm{wt} \%$ and $50 \mathrm{wt} \%$ aqueous $\mathrm{NaOH}$ solutions. A PTFE electrochemical cell was set up with a platinum counter electrode, and a Red-rod reference electrode from Hach ${ }^{\circledR}$. All electrochemical potentials were converted to the normal hydrogen electrode (Red-rod $+129.5 \mathrm{mV}$ vs. NHE). The experiments were carried out with a Schlumberger Solartron potentiostat using a scan rate of $1 \mathrm{mV} / \mathrm{s}$. The open circuit corrosion potential (OPC or $\mathrm{E}_{\text {corr }}$ ) was measured in each test for $2 \mathrm{~h}$, with potentio-dynamic polarization carried out from $-0.2 \mathrm{~V}$ or -0.5 versus $\mathrm{E}_{\text {corr }}$, to $+0.5 \mathrm{~V}$ versus Red-rod reference electrode.

For analyzing the effect of alloying elements, potentio-dynamic measurements on austenitic grade type 304 Stainless steels $(18 \% \mathrm{Cr}-8 \% \mathrm{Ni})$, type 204 stainless steels $(16 \% \mathrm{Cr}-1 \% \mathrm{Ni}-9 \% \mathrm{Mn})$, duplex stainless steel type 2205 $(22 \% \mathrm{Cr}-5 \% \mathrm{Ni})$, and commercially pure nickel alloy 200 $(99 \% \mathrm{Ni})$ were also carried out in $50 \mathrm{wt} \% \mathrm{NaOH}$ at $90{ }^{\circ} \mathrm{C}$. The latter results were then compared to data obtain from type $316 \mathrm{~L}$ stainless steel.

Corrosion rates were calculated from potentiodynamic measurements by (1) extracting the maximum critical current density $\left(i_{\text {corr- }-1}\right)$ at the first active-passive transition in order to get the maximum critical corrosion rate value of the system, and (2) by using linear polarisation resistance method (LPR) in order to measure the corrosion rate at open circuit potentials.

LPR was conducted in the range from -10 to $+10 \mathrm{mV}$ versus $E_{\text {corr }}$ using a scan rate of $1 \mathrm{mV} / \mathrm{s}$. All obtained parameters and associated values are summarized in the "Appendix" section. Current densities were converted into corrosion rates via Faraday's law, with an assumed average metal charge of $\mathrm{n}=2$, atomic weight $\mathrm{M}=55.8 \mathrm{~g} / \mathrm{mol}$ and density of $\rho=8 \mathrm{~g} / \mathrm{cm}^{3}$, and Faraday's constant $\mathrm{F}=96485 \mathrm{C} / \mathrm{mol}$ [23].

Weight loss experiments were performed with one set of type 316L samples exposed at room temperature for 4 months. A second set of samples was tested in a temperature perturbation system, by changing the exposure temperature from 50 to $90{ }^{\circ} \mathrm{C}$ for a period of 35 days. The temperature was altered approximately 4 times per week. This test was designed to simulate heat exchanger intervals, with batch exposure at different temperatures. All weight loss samples were cleaned after testing in an ultrasonic water bath in a mixture of distilled water and acetone, followed by drying and re-weighting. The material loss was calculated based on the exposed surface area of each sample.
One coupon sample was also exposed for 4 months in $50 \% \mathrm{NaOH}$ at $90{ }^{\circ} \mathrm{C}$ to obtain information about the developed surface film. Grazing-incidence X-ray diffraction (GI-XRD) measurements were carried out in a PANalytical $\mathrm{X}$-ray diffraction instrument, by using the following parameter: $3^{\circ}$ incidence angle, start position $[2 \theta]=10.025^{\circ}$, End Position $[2 \theta]=89.975^{\circ}$, Step Size $[2 \theta]=0.05^{\circ}$. These measurements were augmented by X-ray Photoelectron Spectroscopy (XPS) analysis using a Kratos Axis Ultra with monochromatic Al Ka radiation source $(1486.69 \mathrm{eV})$, to obtain information of the chemical composition of the surface film. XPS measurements were obtained using a pass-energy of $80 \mathrm{eV}$, with a step size of $500 \mathrm{meV}$ and a dwell time of $150 \mathrm{~ms}$. The obtained spectra were corrected based on the carbon peak $(\mathrm{C} 1 s)$ position to $284.8 \mathrm{eV}$ and analysed using CasaXPS software (Version 2.3.17). The background was fitted with a Shirley function and the Gauss-Lorentz function was used for peak fitting to quantify the obtained results.

\section{Results and Discussion}

Figure 1a summarizes the electrochemical response of type 316L stainless steel in $50 \mathrm{wt} \%$. NaOH caustic electrolyte. Exposure of stainless steel to $\mathrm{NaOH}$ shows the occurrence of several active to passive transitions, associated with different electrochemical potential domains [24]. The different domains in Fig. 1a are referred to as (1) cathodic region, (2) free corrosion potential $\left(\mathrm{E}_{\mathrm{corr}}\right),(3)$ active peak with active-passive transition, (4) 1st passive domain $\left(\mathrm{E}_{\mathrm{pass}-1}\right)$, (5) 2nd active peak with active to passive transition, (6) second passive domain ( $\left.\mathrm{E}_{\text {pass-2 }}\right)$, (7) 3rd active peak with trans-passivity and oxygen evolution.

In Fig. 1b, the corrosion response of type 316L is compared to austenitic stainless steel types 304 and 204, duplex stainless steel type 2205, and Ni alloy 200. The effect of alloying elements and how these elements affect the electro-chemical response in $50 \% \mathrm{NaOH}$ environments can be assessed, by comparing individual alloy responses. Interestingly, the $\mathrm{E}_{\text {corr }}$ values of all tested materials are very similar, with values close to $-1 \mathrm{~V}$ versus NHE. The value for type 316 reported here correlates with $\mathrm{E}_{\mathrm{corr}}$ values reported in prior investigations of Type 316 in hot concentrated caustic solution [24, 25].

Figure $1 \mathrm{~b}$ clearly points towards a common electrochemical behavior of all four types of stainless steels, in the form of an initial active-passive transition just below $-1 \mathrm{~V}$ versus NHE, followed by a second active-passive transition close to $0 \mathrm{~V}$ versus NHE. The first passive domain $\left(\mathrm{E}_{\mathrm{pass}-1}\right)$ is associated with the presence of a chromium-oxide based passive films $\left(\mathrm{Cr}_{2} \mathrm{O}_{3}\right)$. The occurrence and magnitude of the first active-passive transition is pre-dominantly related to environmental parameters, which was demonstrated, for 


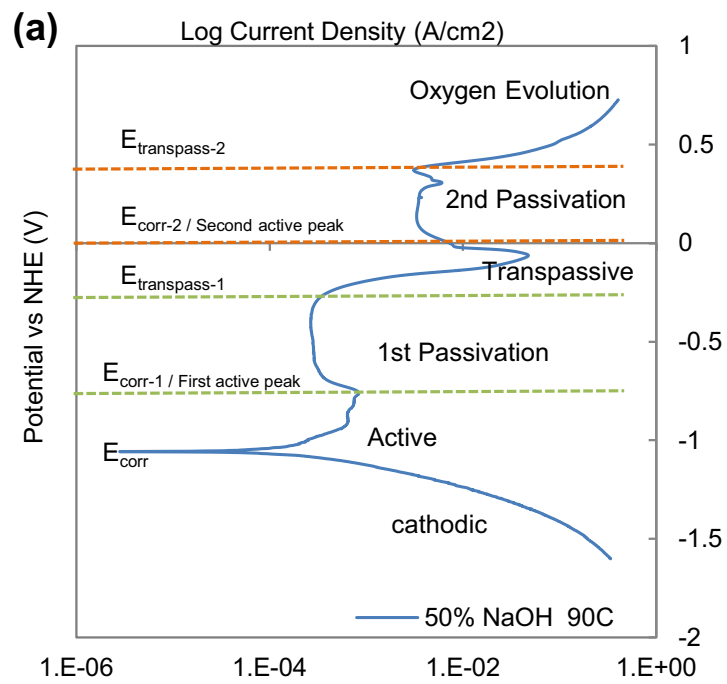

Fig. 1 a Electrochemical response of type 316L in 50\% aerated $\mathrm{NaOH}$ at $90{ }^{\circ} \mathrm{C}$ with potential regions describing the stainless steel behaviour in this environment, and $\mathbf{b}$ potentio-dynamic polarization

example, via a systematic study of type 316 stainless steel in various $\mathrm{HCl}$ concentrations up to $80^{\circ} \mathrm{C}$ [26]. In contrast, by keeping the environment constant, the overall shape of the active-passive transition peak as well as the magnitude is then a function of the chemical composition and alloying elements. The latter is easily demonstrated with duplex stainless steel microstructures, which show a convoluted active-passive transition peak during electrochemical polarisation, representing overlapping chromium-rich ferrite and nickel-rich austenite peaks [27-29].

The second active-passive transition at $0 \mathrm{~V}$ NHE in Fig. $1 \mathrm{~b}$ is also only present for chromium containing stainless steels. This peak is clearly associated with changes of the oxidation state of chromium due to the applied electrochemical potential, referred to as $\mathrm{Cr}$ transpassivity. Nickel alloy 200 shows no activation peak at this potential. The presence of alloying elements in these alloys are then able to induce a 2 nd passive domain ( $\left.\mathrm{E}_{\text {pass- }-2}\right)$, linked to the formation of various oxide and hydroxide films [6, 24]. Based on the analysis of surface films formed in this region, a bi-layer structure with $\mathrm{Cr}$ (III)-barrier layer containing mixed oxidation states of $\mathrm{Cr}(\mathrm{III} / \mathrm{VI})$, covered by an outer hydroxide layer has been reported [24]. At potentials more positive than the 1st passivation region $\left(\mathrm{E}_{\text {pass- }-1}\right)$, a thick $(>100 \mathrm{~nm})$ partially protective $\mathrm{Ni}(\mathrm{OH})_{2}$ layer has also been reported, associated with the formation of thin de-alloyed layers, approaching compositions of binary 50-50 Fe-Ni alloys [30].

The Mn-based type 204 stainless steel seems to be the least corrosion resistant material in this environment,

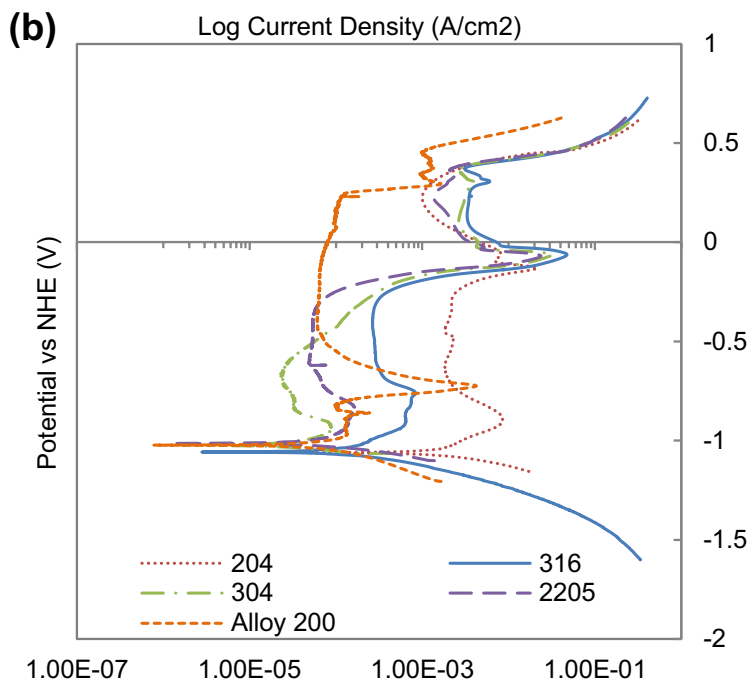

curves of austenitic stainless steel types 316, 304 and 204, duplex stainless steel type 2205, and $\mathrm{Ni}$ alloy 200 in $50 \% \mathrm{NaOH}$ at $90{ }^{\circ} \mathrm{C}$ aerated solution

showing the highest overall current density, followed by type 316L, since Molybdenum does not form passive films in hot caustic environments [6]. Previous work has also revealed the negative influence of Molybdenum on the corrosion resistance of stainless steel in white liquor, facilitating high dissolution rates in the form of $\mathrm{MoO}_{4}^{2}$-ion formation [31].

The electrochemical behavior of commercially pure nickel alloy 200 is different to all stainless steels, showing two active peaks around $-0.75 \mathrm{~V}$ and $+0.3 \mathrm{~V}$ versus NHE, linked by a long passive domain with an inherently low passive current density. The electrochemical behavior therefore indicates three passive regions, due to the $\mathrm{Ni}$ oxidation states $(\mathrm{Ni}+\mathrm{II} /+\mathrm{III})$ that can result in different oxides and hydroxides. The first passive region is close to $\mathrm{E}_{\text {corr }}$, followed by an active-passive transition, and a large 2 nd passive region spanning over more than $800 \mathrm{mV}$. The 3rd active-passive transition than occurs at a potential around $+0.3 \mathrm{~V}$ versus NHE. This is also described in an investigation on the electrochemical behavior of Nickel [32]. The Mn-containing stainless steel Type 204 contains less than $1 \% \mathrm{Ni}$, and no peak is therefore observed at $+0.3 \mathrm{~V}$ versus NHE, supporting the observation that this peak is associated with $\mathrm{Ni}$ oxidation. All other Ni-containing stainless steels, types 304, 316 and 2205, show a small active-passivation transition at this potential, before leading into the oxygen evolution regime.

The duplex grade 2205 and both austenitic types 304 and 316 stainless steels clearly show similar electro-chemical behavior, presenting two prominent passive regions. The differences in the current density and the length of the passive 
regions are certainly due to the different contents of chromium and nickel of each material. Type 316 stainless steel seems to show higher corrosion susceptibility than type 304 and 2205 stainless steel (Fig. 1). Further investigations were therefore directed to better understand how environmental exposure parameters affect the corrosion performance of type 316 stainless steel.

\subsection{Effect of Temperature and $\mathrm{NaOH}$ Concentration}

A comparison of type $316 \mathrm{~L}$ in aerated $50 \mathrm{wt} \%, 40 \mathrm{wt} \%$ and $30 \mathrm{wt} \% \mathrm{NaOH}$ at different temperatures is presented in Fig. 2. The length of the 1st passive region shows a direct relationship

(a)
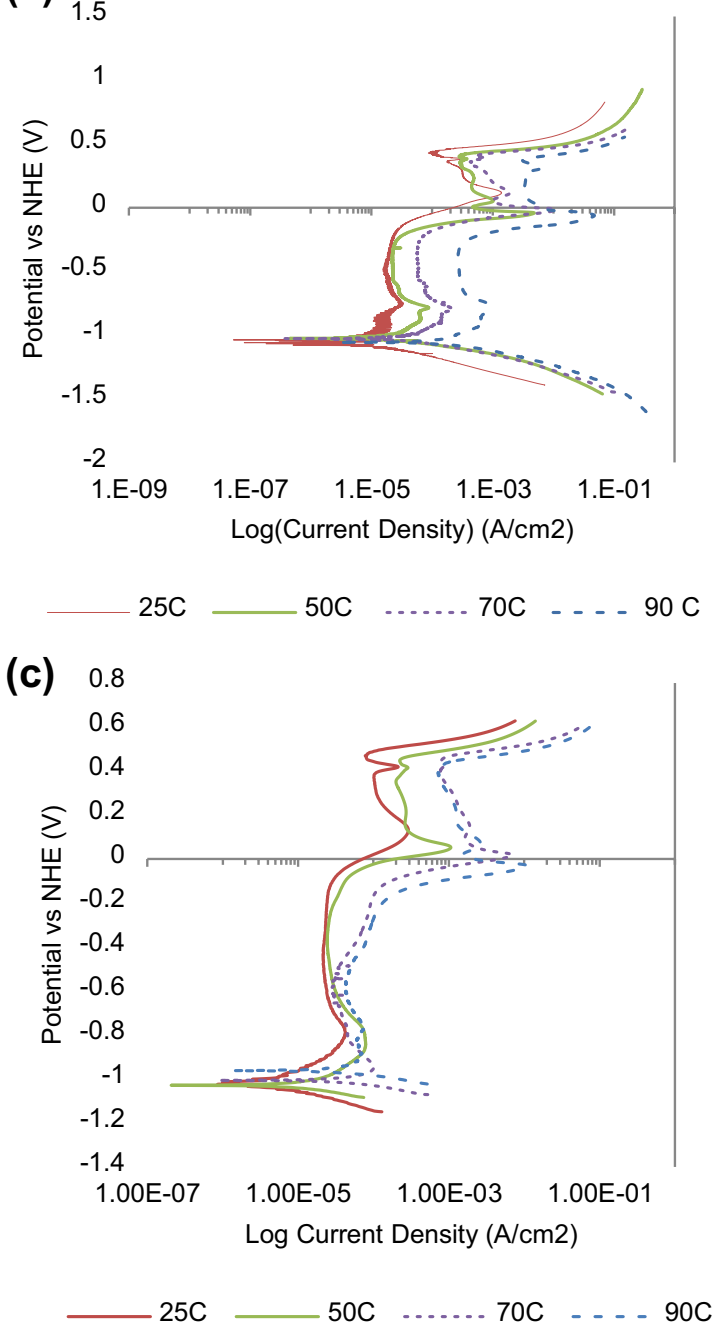

to the measured current density $\left(\mathrm{i}_{\text {pass } 1}\right)$ in this region. The latter has been found to increase with temperature. Figure $2 d$ shows the effect of temperature and $\mathrm{NaOH}$ concentrations on the stability of the measured passive domain.

The second passive domain in Fig. 2a-c seems to posses similar lengths and shapes for all investigated $\mathrm{NaOH}$ concentrations. In general, the overall current density observed in all different potential domains significantly increases with increasing exposure temperature, summarized in Fig. $2 d$. The current density of the transition zones and the 1st passive domains was therefore extracted to estimate corrosion rates via Faraday's law, with all results summarized in the "Appendix" section.

(b)
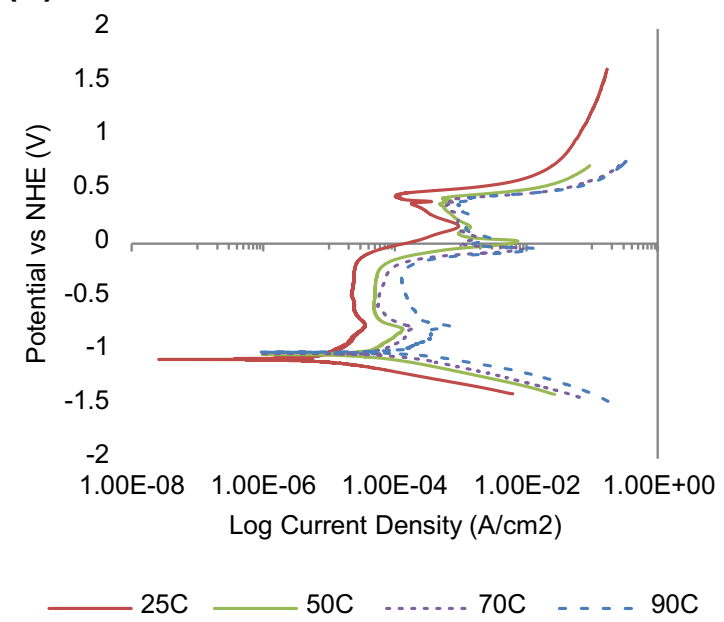

(d)

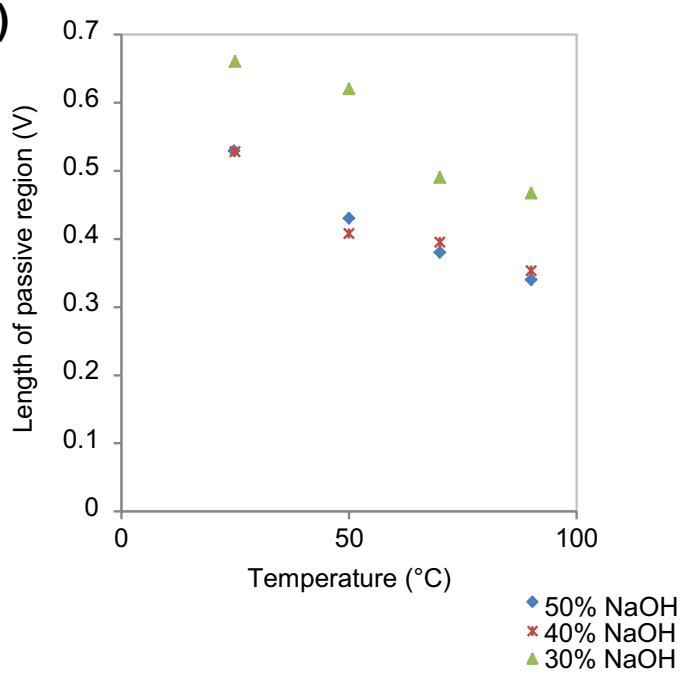

Fig. 2 Polarization curves of type 316L at different temperatures in aerated condition, with a 50\% $\mathrm{NaOH}, \mathbf{b} 40 \% \mathrm{NaOH}$, c $30 \% \mathrm{NaOH}$, and d summarizing the length of the passive region at different temperatures 


\subsection{Effect of De-aeration}

The effect of solution de-aeration on the electrochemical behavior in $40 \mathrm{wt} \%$ and $50 \mathrm{wt} \% \mathrm{NaOH}$ is summarized in Fig. 3. The polarization curves for the aerated and de-aerated systems show very similar electrochemical behavior. Key difference between both systems is the measured current density, and the reduced length of the passive domain. In general, the absence of oxygen tends to raise the current density, compared to the aerated systems; hence it increases the corrosion rate and decreases the resistance of stainless steel in these environments.

The critical maximum corrosion rate in aerated $50 \mathrm{wt} \%$ $\mathrm{NaOH}$ at $90{ }^{\circ} \mathrm{C}$ reached $9.5 \mathrm{~mm} /$ year, which is, however, half the critical corrosion rated observed in the same system without oxygen, with a corrosion rate of nearly $18 \mathrm{~mm} /$ year. The same effect is observed at the free corrosion potential in which the corrosion rate of $0.27 \mathrm{~mm} /$ year calculated from the LPR at $50 \mathrm{wt} \% \mathrm{NaOH}$ at $90{ }^{\circ} \mathrm{C}$ this value is around the half compared with in the same system in de-aerated conditions that reached $0.48 \mathrm{~mm} /$ year. This indicates that the presence of oxygen supports stabilization of the passive surface film in caustic environments. This could also explain the strong effect of temperature on the corrosion behavior, since the solubility of oxygen in aqueous solution decreases with increasing temperature [33]. The environment contains hydroxide ions, supporting formation of Nickel-hydroxide, which has been reported to be protective [13, 24, 34].

The effect of oxygen in $30 \mathrm{wt} \% \mathrm{NaOH}$ solution is shown in Fig. 4, Interestingly, a slightly different material response was found in this environment. The presence of oxygen increased the current density in $30 \mathrm{wt} \% \mathrm{NaOH}$ at room temperature, compared to the de-aerated system. However, at $90{ }^{\circ} \mathrm{C}$ the temperature seems to accelerate the corrosion rate of the de-aerated system, portraying similar behavior as the $40 \mathrm{wt} \%$ and $50 \mathrm{wt} \% \mathrm{NaOH}$ environments. This observation also supports a strong effect of exposure temperature. The oxygen in $30 \mathrm{wt} \%$. $\mathrm{NaOH}$ solution may contribute to the cathodic corrosion reaction, facilitating higher dissolution current densities and therefore higher

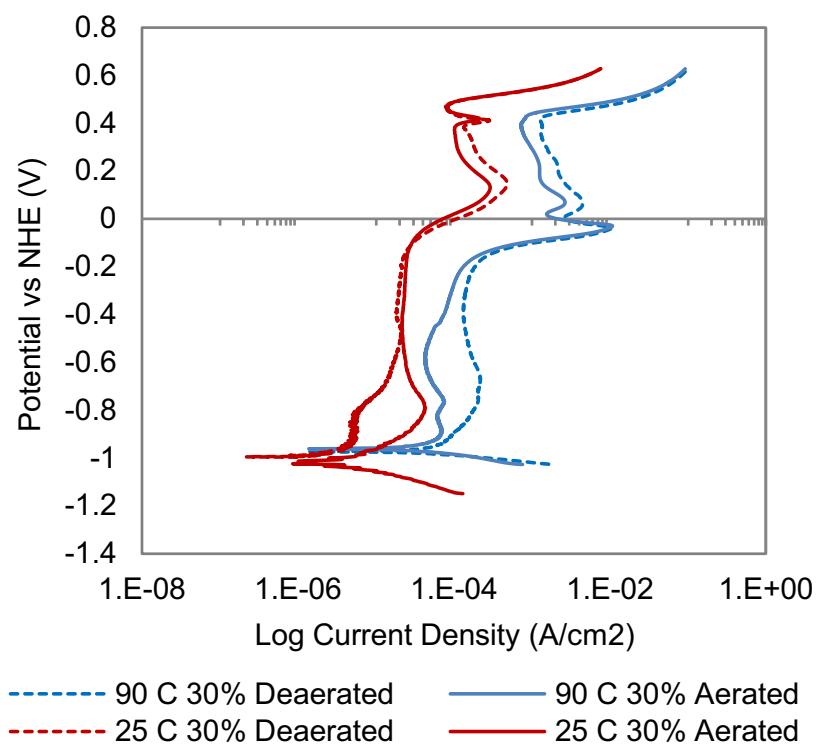

Fig. 4 Effect of oxygen and temperature on the electrochemical behaviour of Type $316 \mathrm{~L}$ in $30 \% \mathrm{NaOH}$ at $25^{\circ} \mathrm{C}$ and $90{ }^{\circ} \mathrm{C}$
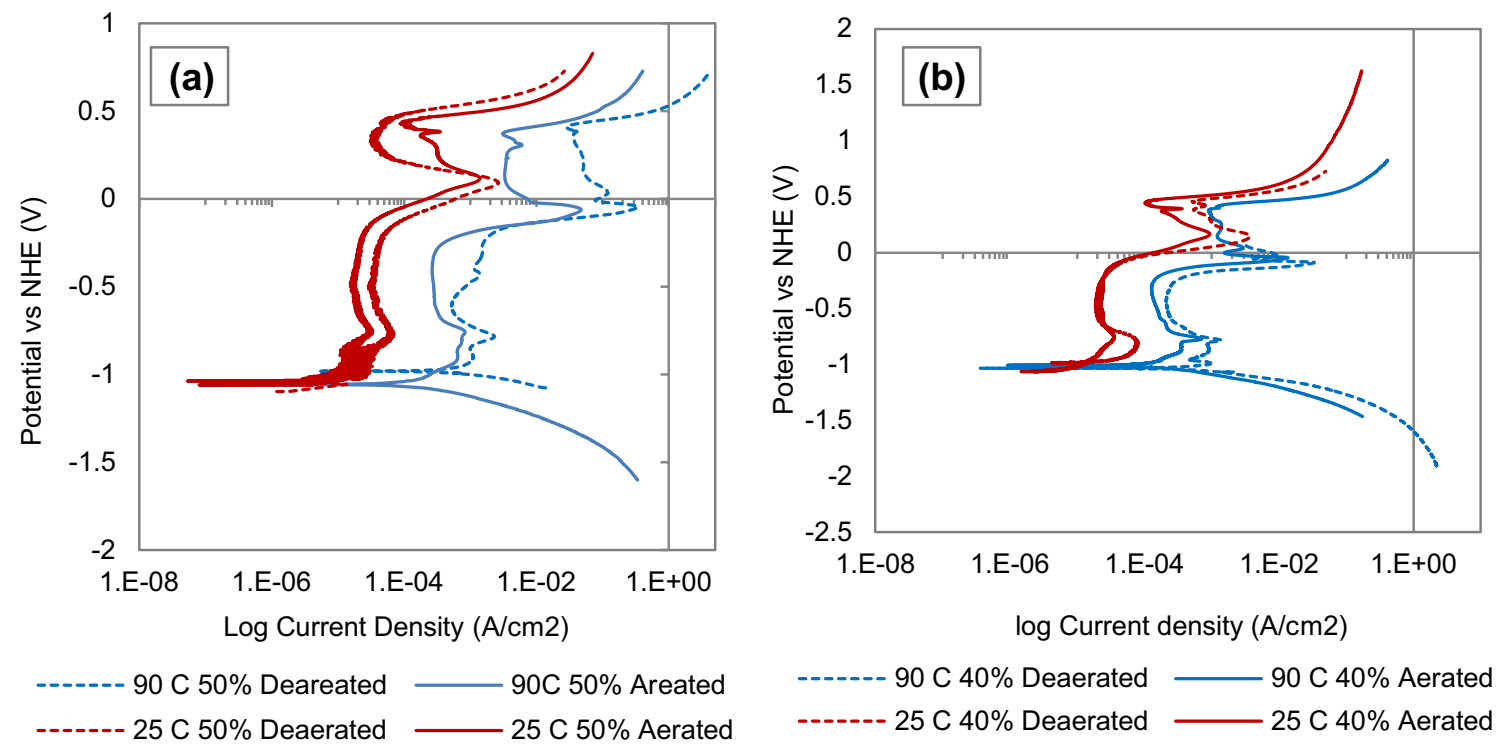

Fig. 3 a Effect of oxygen and temperature on the electrochemical behavior of Type $316 \mathrm{~L}$ in $50 \% \mathrm{NaOH}$ at $25{ }^{\circ} \mathrm{C}$ and $90{ }^{\circ} \mathrm{C}$, and $\mathbf{b}$ in $40 \% \mathrm{NaOH}$ at $25^{\circ} \mathrm{C}$ and $90^{\circ} \mathrm{C}$ 
corrosion rates. The solubility of oxygen in $\mathrm{NaOH}$ solution also increases with decreasing $\mathrm{NaOH}$ concentration [35].

\section{Summary of Passive Behaviour}

Figure 5 plots the passive current densities of the first passive region $\left(i_{\text {pass } 1}\right.$ ) against the length of this passive domain for both, aerated and de-aerated $\mathrm{NaOH}$ systems. The graph clearly shows the effect of temperature on passivity. When the temperature is increased the passive current density increases and the length of the passive region decreases. Hence, it can be established that key parameter for the corrosion performance of type 316 stainless steel in this environment is temperature.

The effect of de-aeration is also shown in Fig. 5. In the aerated environment, most points lie between 0.4 and $0.55 \mathrm{~V}$, with passive current densities of $2-7 \times 10^{-5} \mathrm{~A} /$ $\mathrm{cm}^{2}$. In de-aerated environment, most data points lie between 0.3 and $0.45 \mathrm{~V}$, with passive current densities of $2 \times 10^{-4}-2.4 \times 10^{-5} \mathrm{~A} / \mathrm{cm}^{2}$. This direct comparison clearly emphasizes the effect of aeration on the passive region.

\subsection{Critical Corrosion Rates: Calculated at the Highest Active Peak}

The corrosion rate of all caustic environments using the highest peak on the potentio-dynamic polarization curve is summarised in Fig. 6, spanning more than 1 order of magnitude. Type $316 \mathrm{~L}$ stainless steel exposed to aerated $30 \mathrm{wt} \% \mathrm{NaOH}$ solution at $25{ }^{\circ} \mathrm{C}$ showed critical corrosion rates of $0.38 \mathrm{~mm} /$ year, which increased with temperatures to

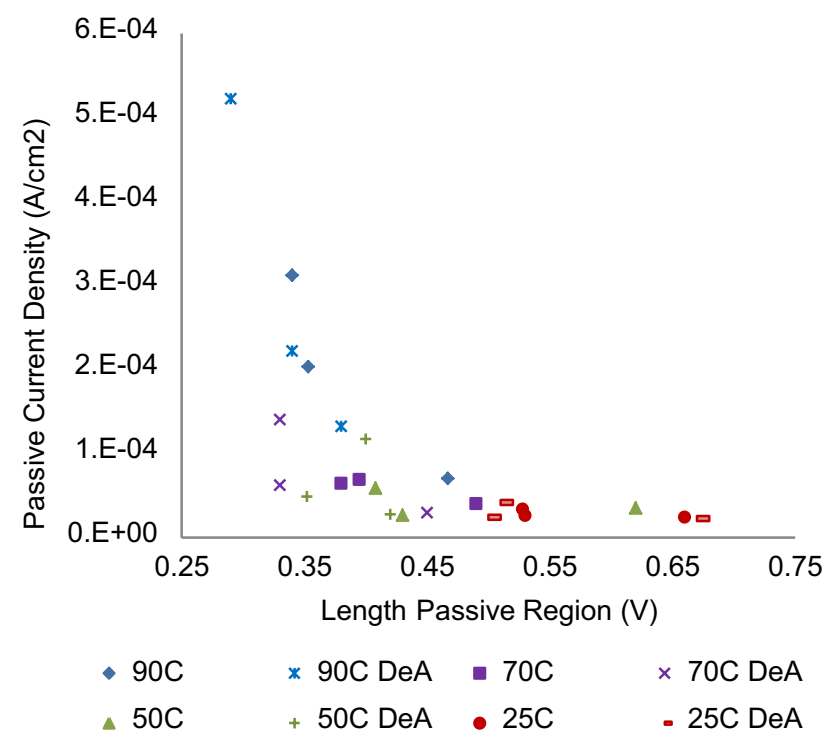

Fig. 5 Length of 1 st passive domain versus current density ( 1 st $\mathrm{i}_{\text {pass } 1}$ ) in all investigated aerated (full symbols) and de-aerated (open symbols, DeA) $\mathrm{NaOH}$ systems
$0.8 \mathrm{~mm} /$ year. Consequently, the temperature effects are less corrosive in the $30 \mathrm{wt} \%$ environment, than with exposure to more concentrated $\mathrm{NaOH}$ environments.

Most of these corrosion rates are much higher than the corrosion rates calculated at the open circuit potential showed in Fig. 7. As the potential is increased by the potentiostat the metal sample reaches the active state in which the anodic dissolution of the metal is represented by the increasing of current in the system. The critical corrosion rate calculated using the maximum current density from the active peak shows the worst-case scenario of the active behavior of the sample and due to this reason the critical corrosion rates have a vast difference between the ones calculated with the LPR method.

\subsection{Corrosion Rates: Calculated at the Open Circuit Potential with LPR}

The corrosion rate of all caustic environments using the LPR method is summarised in Fig. 7. Type 316L stainless steel exposed to aerated $50 \mathrm{wt} \% \mathrm{NaOH}$ solution at $25^{\circ} \mathrm{C}$ shows corrosion rates of $0.023 \mathrm{~mm} / \mathrm{year}$. This value is expected for stainless steel working in caustic environments. However, when the temperature is increased above $50{ }^{\circ} \mathrm{C}$ and the system is de-aerated the corrosion rates even at the free corrosion potential reach up to nearly $0.5 \mathrm{~mm} /$ year, 21 times the value at room temperature. This behavior seems to be related to the diminution in the length of the passive region mentioned before in Fig. 5.

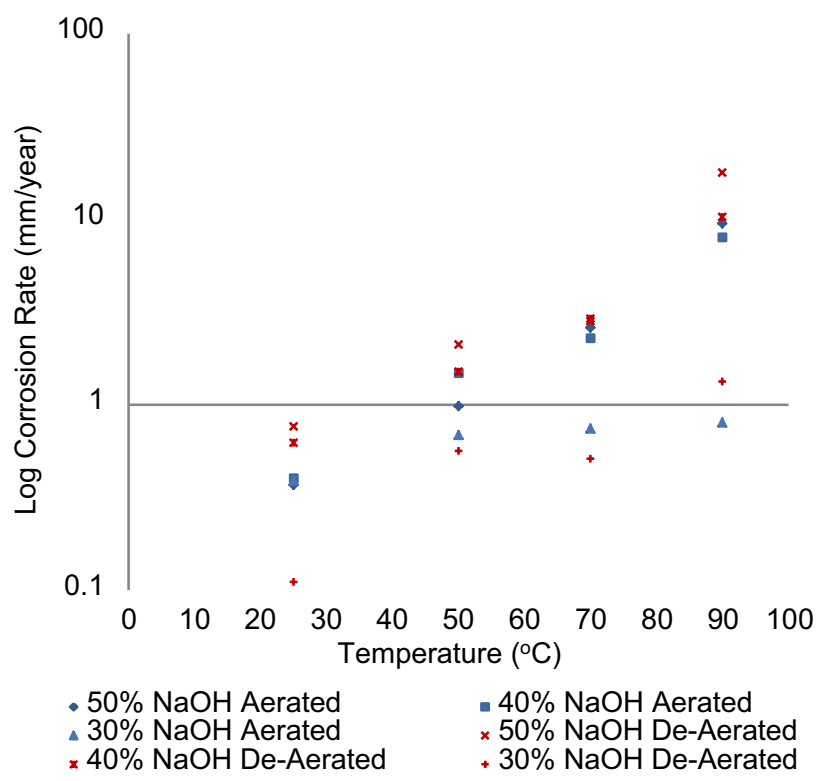

Fig. 6 Corrosion rate versus temperature of Type 316L stainless steel in aerated and de-aerated 30\%, 40\% and 50\% $\mathrm{NaOH}$ solutions From the highest active peak of the polarization curve 


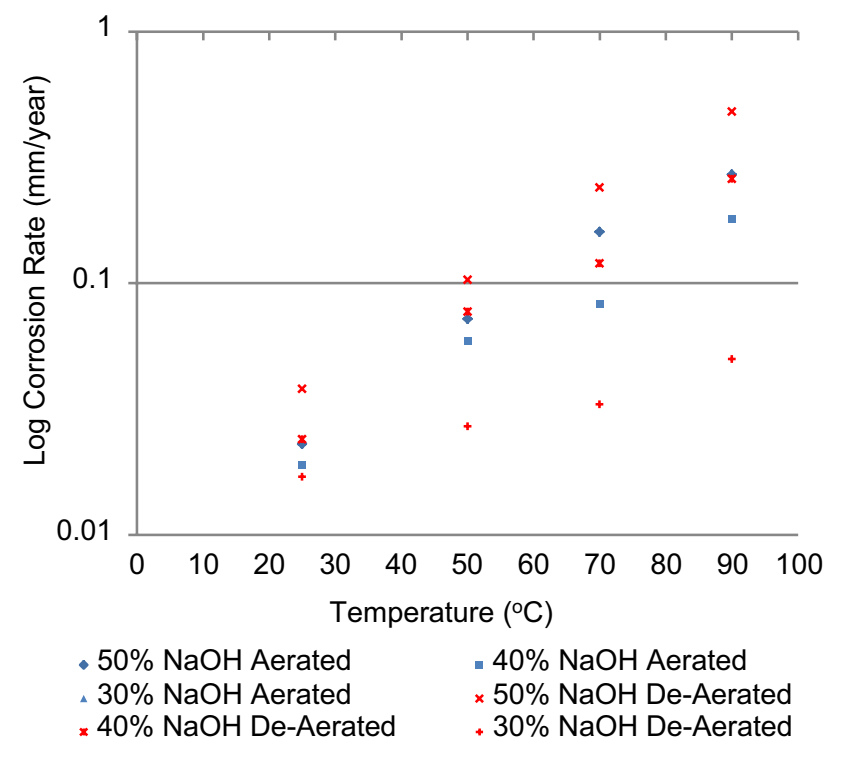

Fig. 7 Corrosion rate versus temperature of Type 316L stainless steel in aerated and de-aerated $30 \%, 40 \%$ and $50 \% \mathrm{NaOH}$ solutions from LPR

\subsection{Weight Loss Measurements}

Figure 8a shows weight loss measurements at room temperature with exposure up to 4 months. All curves show the same trend of a reduction in weight loss rate over time, indicating a parabolic weight loss trend. Higher $\mathrm{NaOH}$ concentrations show higher material loss, supporting the trends reported in the electrochemical investigations in Fig. 2. If the total weight loss after 4 months is converted into a mean corrosion rate, values of $0.07 \mathrm{~mm} /$ year for $30 \% \mathrm{NaOH}$, $0.12 \mathrm{~mm} /$ year for $40 \mathrm{wt} \% \mathrm{NaOH}$, and $0.16 \mathrm{~mm} /$ year for $50 \mathrm{wt} \% \mathrm{NaOH}$ are obtained.

A second weight loss test by including changes in temperature of the environment was performed, to simulate heat exchanger temperature perturbations. The results of this experiment are illustrated in Fig. 8b. The experiment was carried out for a period of 5 weeks with exposure in caustic solutions of $30 \mathrm{wt} \%, 40 \mathrm{wt} \%$ and $50 \mathrm{wt} \%$. The corrosion rate increased in each case with temperature. Exposure to $30 \mathrm{wt} \% \mathrm{NaOH}$ resulted in corrosion rates of $0.38 \mathrm{~mm} /$ year, with $40 \mathrm{wt} \% \mathrm{NaOH}$ giving $0.98 \mathrm{~mm} / \mathrm{year}$, and $50 \mathrm{wt} \%$ the corrosion rate reached $1.9 \mathrm{~mm} /$ year. Comparing these values with room temperature exposure, it can be confirmed that the effect of temperature is detrimental to the corrosion behavior of stainless steel at high concentrations of caustic solutions. All the measured values even the less concentrated solutions (30 wt \%) are outside the general corrosion rate allowance, with the data in Fig. 8b showing an acceleration of corrosion rate over time.

\subsection{Effect of Surface Film Formation}

Visible corrosion attack on the surface of samples exposed in the weight loss tests were observed, with surfaces covered by a dark film. The presence of this film is believed to be key to understand the corrosion performance and passivity of type 316 stainless steel in caustic environments. A noticeable dark film can be recognized after an immersion of the sample in caustic solutions at temperatures between 50 and $90{ }^{\circ} \mathrm{C}$. Exposure at temperature below $50{ }^{\circ} \mathrm{C}$ did not show any presence of the dark film. Instead,
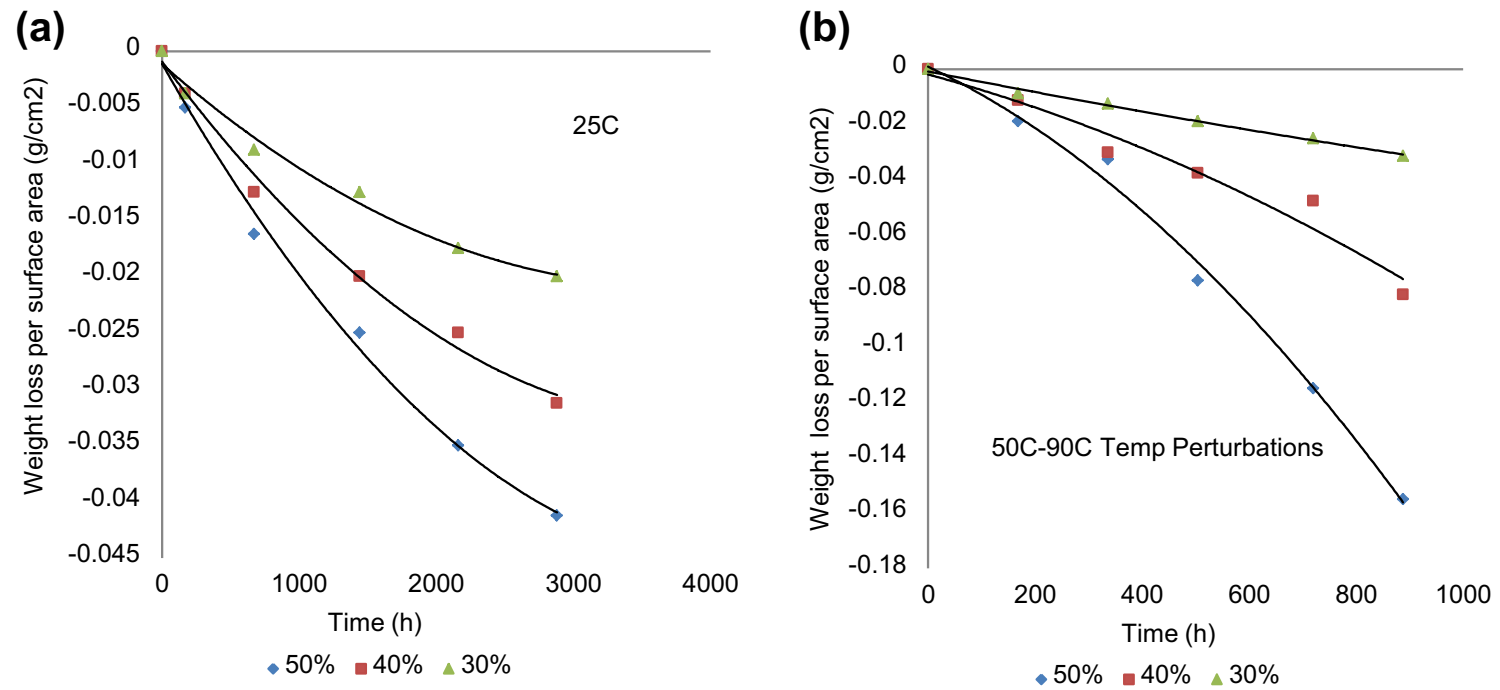

Fig. 8 a Weight loss curves of type 316L stainless steel in 50\%, 40\%, and 30\% $\mathrm{NaOH}$ at $25{ }^{\circ} \mathrm{C}$, with, b showing weight loss curves in $50 \%$, $40 \%$ and $30 \% \mathrm{NaOH}$ with temperature perturbations of $50{ }^{\circ} \mathrm{C}$ to $90^{\circ} \mathrm{C}$ 
a more yellow/orange corrosion product was formed on the surface.

The surface of a sample exposed for 4 months in 50\% $\mathrm{NaOH}$ at $90^{\circ} \mathrm{C}$ was analysed by GI-XRD, with the spectrum of the dark surface film shown in Fig. 9. The observed film consists of a mixture of iron oxide hydroxide $(\mathrm{FeO}(\mathrm{OH}))$ and nickel oxide (NiO), with the fcc austenitic stainless steel

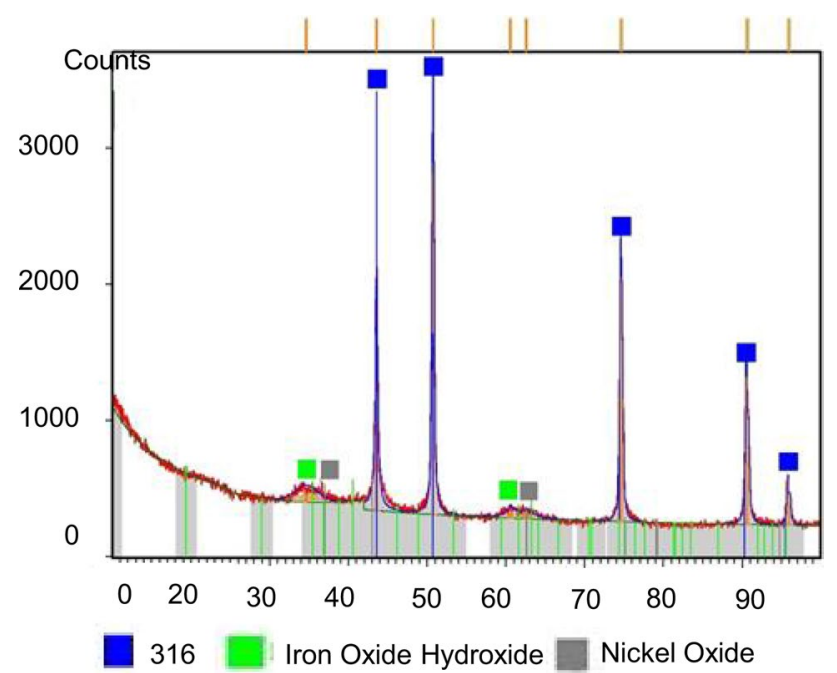

Fig. 9 GI-XRD analysis of the black surface film after immersion in $50 \% \mathrm{NaOH}$ at $90^{\circ} \mathrm{C}$ peaks also present. Ni-oxide typically presents a black color [34].

In addition XPS data confirm the presence of iron and nickel oxides/hydroxides in the near surface region. Figure 10a shows the obtained $\mathrm{Fe} 2 p$ spectra of the dark surface film, with comparison to a pristine type $316 \mathrm{~L}$ reference surface. The pristine reference sample contains iron metal $(12.7 \%)$ and iron oxide/hydroxide peaks (46.7\%), with the presence of iron oxide/hydroxides related to the passive film on stainless steels $[36,37]$. The reference surface condition also contained $4.2 \%$ chromium metal and $27.4 \%$ chromium oxide/hydroxides. In contrast, the surface covered in dark corrosion products revealed the absence of chromium.

The obtained Ni $2 p$ spectra is shown in Fig. 10b. The type 316 reference specimen indicated a nickel metal peak at $852.2 \mathrm{eV}$ with a FWHM of $1 \mathrm{eV}$ contributing $4.3 \%$ of the near surface composition. A nickel hydroxide peak $\left(\mathrm{Ni}(\mathrm{OH})_{2}\right)$ is present at $855.2 \mathrm{eV}(\mathrm{FWHM} 2.2 \mathrm{eV})$ contributing $1.8 \%$ to the composition. The nickel content of the dark corrosion products is significantly increased compared to the film on the reference specimen. The nickel metal $(852.1 \mathrm{eV}$, FWHM $1.8 \mathrm{eV})$ content is in the same order of magnitude $3.4 \%$, with nickel oxides and hydroxides believed to be the main component of the dark corrosion products with $63 \%$.

(b)

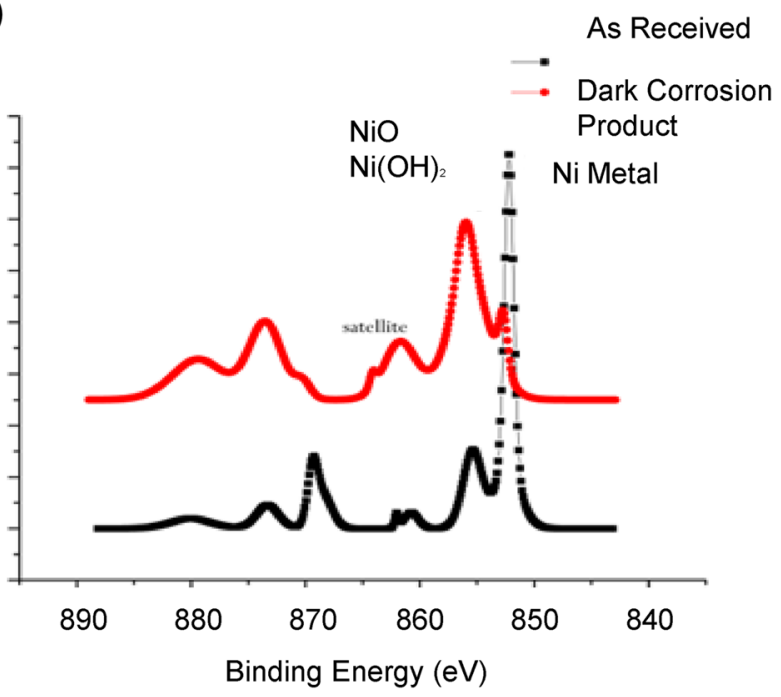

Fig. 10 a Fe $2 p$ spectra and b Ni $2 p$ spectra of reference specimen and dark corrosion products with possible XRD peak fits 
This supports the observation that the dark corrosion layer is made out of $\mathrm{NiO}$ and $\mathrm{Ni}(\mathrm{OH})_{2}$. A $\mathrm{NiO}$ peak was determined at 853.6 with a FWHM value of $1.5 \mathrm{eV}$, with the $\mathrm{Ni}(\mathrm{OH})_{2}$ peak at $855.4 \mathrm{eV}(\mathrm{FWHM} 1.8 \mathrm{eV})$. The obtained nickel peak positions are in good agreement with literature data [38-40]. The exact distribution of nickel oxide and hydroxide in the layer was not determined, due to the presence of the satellite peak at $861 \mathrm{eV}$. The role of temperature on the stability of $\mathrm{NiO}$ and $\mathrm{Ni}(\mathrm{OH})_{2}$ is currently subject of further investigations, since it is not clear why higher corrosion rates are observed when this film is present.

\section{Conclusions}

- Type 316 stainless steel reaches a maximum critical corrosion rate of $\approx 18 \mathrm{~mm} /$ year in de-aerated $50 \mathrm{wt} \% \mathrm{NaOH}$ solution at $90{ }^{\circ} \mathrm{C}$ at the peak of the active state, however the corrosion rate in the same environment at open circuit potential reaches a maximum of $\approx 0.5 \mathrm{~mm} /$ year.

- After exposure to concentrated caustic solutions at temperature above $50{ }^{\circ} \mathrm{C}$, stainless steel surfaces are covered by a black surface film predominantly made of nickel oxide and hydroxides.

- The exposure temperature is a key parameter in the performance of type 316L stainless steel in caustic environments, affecting the length of the passive domain and corrosion rate.

- De-aeration increased the corrosion rate of type $316 \mathrm{~L}$ stainless steel in hot caustic $\mathrm{NaOH}$ environment, but exposure to $30 \mathrm{wt} \% \mathrm{NaOH}$ at RT showed the opposite trend.

Acknowledgements The authors acknowledge the funding through SENESCYT (Grant No AR2Q-000188-2015. Top Universities Scholarship 2015)—Ecuador for sponsoring this postgraduate research project.

Open Access This article is distributed under the terms of the Creative Commons Attribution 4.0 International License (http://creat ivecommons.org/licenses/by/4.0/), which permits unrestricted use, distribution, and reproduction in any medium, provided you give appropriate credit to the original author(s) and the source, provide a link to the Creative Commons license, and indicate if changes were made.
Appendix: Electrochemistry and Corrosion Data for Type 316L Stainless Steel

\begin{tabular}{|c|c|c|c|c|}
\hline Temperature $\left({ }^{\circ} \mathrm{C}\right)$ & 90 & 70 & 50 & 25 \\
\hline \multicolumn{5}{|c|}{ Aerated $50 w t \% \mathrm{NaOH}$} \\
\hline E-Corr (V) & -1.056 & -1.028 & -1.0271 & -1.059 \\
\hline $\begin{array}{l}\text { Critical } \mathrm{I}_{\text {Corr-1 }}(\mathrm{A} / \\
\left.\mathrm{cm}^{2}\right)\end{array}$ & $8.30 \mathrm{E}-04$ & $2.21 \mathrm{E}-04$ & $8.60 \mathrm{E}-05$ & $3.23 \mathrm{E}-05$ \\
\hline $\begin{array}{l}\text { Critical } \mathrm{E}_{\text {corr } 1} \text {-Corr } \\
\text { (V) }\end{array}$ & -0.757 & -0.802 & -0.79 & -0.771 \\
\hline $\begin{array}{l}\text { Critical corr rate } \\
\text { (mm/year) }\end{array}$ & 9.46 & 2.6 & 0.98 & 0.368 \\
\hline $\mathrm{E}_{\text {pass-1 }}(\mathrm{V})$ & -0.633 & -0.586 & -0.609 & -0.7 \\
\hline $\mathrm{I}_{\text {pass-1 }}\left(\mathrm{A} / \mathrm{cm}^{2}\right)$ & $3.12 \mathrm{E}-04$ & $6.41 \mathrm{E}-05$ & $2.65 \mathrm{E}-05$ & $2.61 \mathrm{E}-05$ \\
\hline $\mathrm{E}_{\text {transpass-1 }}(\mathrm{V})$ & -0.37 & -0.228 & -0.316 & -0.149 \\
\hline $\mathrm{E}_{\text {pass-2 }}(\mathrm{V})$ & -0.0211 & 0.0285 & -0.014 & 0.189 \\
\hline $\mathrm{I}_{\text {pass-2 }}\left(\mathrm{A} / \mathrm{cm}^{2}\right)$ & $3.94 \mathrm{E}-03$ & $1.26 \mathrm{E}-03$ & $6.32 \mathrm{E}-04$ & $4.50 \mathrm{E}-04$ \\
\hline $\mathrm{E}_{\text {transpass-2 }}(\mathrm{V})$ & 0.35 & 0.398 & 0.357 & 0.44 \\
\hline $\begin{array}{l}\text { Resistance polariza- } \\
\text { tion }(\Omega)\end{array}$ & 332 & 453 & 1020 & 3218 \\
\hline $\begin{array}{l}\text { Corrosion rate }(\mathrm{mm} / \\
\text { year) }\end{array}$ & 0.27 & 0.16 & 0.072 & 0.023 \\
\hline \multicolumn{5}{|l|}{ Aerated $40 w t \% \mathrm{NaOH}$} \\
\hline E-Corr (V) & -1.072 & -1.021 & -1.034 & -1.076 \\
\hline $\begin{array}{l}\text { Critical } \mathrm{I}_{\text {Corr-1 }}(\mathrm{A} / \\
\left.\mathrm{cm}^{2}\right)\end{array}$ & $7.00 \mathrm{E}-04$ & $2.00 \mathrm{E}-04$ & $1.30 \mathrm{E}-04$ & $3.44 \mathrm{E}-05$ \\
\hline $\begin{array}{l}\text { Critical } \mathrm{E}_{\text {corr } 1} \text {-Corr } \\
\text { (V) }\end{array}$ & -0.773 & -0.82 & -0.8071 & -0.782 \\
\hline $\begin{array}{l}\text { Critical corr rate } \\
(\mathrm{mm} / \text { year })\end{array}$ & 7.97 & 2.28 & 1.48 & 0.401 \\
\hline $\mathrm{E}_{\text {pass-1 }}(\mathrm{V})$ & -0.624 & -0.645 & -0.708 & -0.704 \\
\hline $\mathrm{I}_{\text {pass-1 }}\left(\mathrm{A} / \mathrm{cm}^{2}\right)$ & $2.03 \mathrm{E}-0.4$ & $6.87 \mathrm{E}-05$ & $5.87 \mathrm{E}-05$ & $3.35 \mathrm{E}-05$ \\
\hline $\mathrm{E}_{\text {transpass-1 }}(\mathrm{V})$ & -0.34 & -0.25 & -0.296 & -0.176 \\
\hline $\mathrm{E}_{\text {pass-2 }}(\mathrm{V})$ & -0.0183 & -0.0123 & 0.0655 & 0.18 \\
\hline $\mathrm{I}_{\text {pass-2 }}\left(\mathrm{A} / \mathrm{cm}^{2}\right)$ & $1.88 \mathrm{E}-03$ & $1.28 \mathrm{E}-03$ & $1.20 \mathrm{E}-03$ & $2.45 \mathrm{E}-04$ \\
\hline $\mathrm{E}_{\text {transpass-2 }}(\mathrm{V})$ & 0.355 & $7.73 \mathrm{E}-04$ & 0.39 & 0.409 \\
\hline $\begin{array}{l}\text { Resistance polariza- } \\
\quad \text { tion }(\Omega)\end{array}$ & 416 & 884 & 1265 & 3984 \\
\hline $\begin{array}{l}\text { Corrosion rate }(\mathrm{mm} / \\
\text { year) }\end{array}$ & 0.18 & 0.083 & 0.059 & 0.019 \\
\hline \multicolumn{5}{|l|}{ Aerated $30 w t \% \mathrm{NaOH}$} \\
\hline E-Corr (V) & -0.963 & -1 & -1.03 & -1.024 \\
\hline $\begin{array}{l}\text { Critical I } \mathrm{I}_{\text {Corr-1 }}(\mathrm{A} / \\
\mathrm{cm}^{2} \text { ) }\end{array}$ & $7.00 \mathrm{E}-05$ & $6.50 \mathrm{E}-05$ & $6.0 \mathrm{E}-05$ & $3.40 \mathrm{E}-05$ \\
\hline $\begin{array}{l}\text { Critical } \mathrm{E}_{\text {corr } 1} \text {-Corr } \\
\text { (V) }\end{array}$ & -0.896 & -0.949 & -0.801 & -0.85 \\
\hline $\begin{array}{l}\text { Critical corr rate } \\
\text { (mm/year) }\end{array}$ & 0.797 & 0.741 & 0.684 & 0.388 \\
\hline $\mathrm{E}_{\text {pass-1 }}(\mathrm{V})$ & -0.8595 & -0.807 & -0.6 & -0.6 \\
\hline $\mathrm{I}_{\text {pass-1 }}\left(\mathrm{A} / \mathrm{cm}^{2}\right)$ & $7.00 \mathrm{E}-05$ & $4.00 \mathrm{E}-05$ & $3.5 \mathrm{E}-05$ & $2.40 \mathrm{E}-05$ \\
\hline
\end{tabular}




\begin{tabular}{lllll}
\hline Temperature $\left({ }^{\circ} \mathrm{C}\right)$ & 90 & 70 & 50 & 25 \\
\hline $\mathrm{E}_{\text {transpass- }}(\mathrm{V})$ & -0.2 & -0.187 & -0.11 & -0.133 \\
$\mathrm{E}_{\text {pass-2 }}(\mathrm{V})$ & 0.0118 & 0.082 & 0.108 & 0.285 \\
$\mathrm{I}_{\text {pass-2 }}\left(\mathrm{A} / \mathrm{cm}^{2}\right)$ & $1.60 \mathrm{E}-03$ & $1.1 \mathrm{E}-03$ & $3.50 \mathrm{E}-04$ & $1.13 \mathrm{E}-04$ \\
$\mathrm{E}_{\text {transpass-2 }}(\mathrm{V})$ & 0.441 & 0.35 & 0.421 & 0.442 \\
$\begin{array}{l}\text { Resistance polariza- } \\
\quad \text { tion }(\Omega)\end{array}$ & 2147 & 2981 & 3658 & 4932 \\
$\quad \begin{array}{llll}\text { Corrosion rate }(\mathrm{mm} / \\
\quad 0.035\end{array}$ & 0.024 & 0.020 & 0.015 \\
$\quad$ & & & & \\
\hline
\end{tabular}

\section{References}

1. L. Esteves, M. Cardoso, V. de Freitas Cunha Lins. Corrosion behavior of duplex and lean duplex stainless steels in pulp mill. Mater. Res. (2018). https://doi. org/10.1590/1980-5373-mr-2017-0148

2. A.R. Khalifeh et al., Stress corrosion cracking of a circulation water heater tubesheet. Eng. Fail. Anal. 78, 55-66 (2017)

3. M.A. Rao, R. Sekhar Babu, M.V. Pavan Kumar, Stress corrosion cracking failure of a SS $316 \mathrm{~L}$ high pressure heater tube. Eng. Fail. Anal. 90, 14-22 (2018)

4. B. Krawczyk et al., Atmospheric chloride-induced stress corrosion cracking of laser engraved type 316L stainless steel. Corros. Sci. 142, 93-101 (2018)

5. H. Feng et al., Corrosion behavior of super duplex stainless steel S32750 in white liquor. Int. J. Electrochem. Sci. 10, 4116-4128 (2015)

6. A. Bhattacharya, P.M. Singh, Electrochemical behaviour of duplex stainless steels in caustic environment. Corros. Sci. 53(1), 71-81 (2011)

7. K.R. Chasse, P.M. Singh, Corrosion study of super ferritic stainless steel UNS S44660 (26Cr-3Ni-3Mo) and several other stainless steel grades (UNS S31603, S32101, and S32205) in caustic solution containing sodium sulfide. Metall. Mater. Trans. A 44(11), 5039-5053 (2013)

8. E. Mattsson, Basic Corrosion Technology for Scientists and Engineers (Halsted Press, Ellis Horwood, 1989)

9. C. Reid, Stress corrosion cracking of austenitic and duplex stainless steels in the kraft pulp mill, in: TAPPI Engineering/Process and Product Quality Conference, Anaheim, CA, USA (1999)

10. P.M. Singh, A. Anaya, K. Frey, J. Mahmood, Corrosivity of Black Liquors-Role of Wood Species Pulped (Institute of Paper Science and Technology Atlanta, Georgia, 2001)

11. A. Wensley, Corrosion of carbon and stainless steels in kraft digesters. NACE Corrosion, Paper No. 589, Houston, CA, USA (2000)

12. INCO, Corrosion Resistance of the Austenitic Chromium-Nickel Stainless Steels in Chemical Environments. Publication 2828, New York. USA. The Authors (1963)

13. A.R. McIlree, H.T. Michels, Stress corrosion behavior of $\mathrm{Fe}-\mathrm{Cr}-$ $\mathrm{Ni}$ and other alloys in high temperature caustic solutions. Corrosion 33(2), 60-67 (1977)

14. V.S. Sastri, E. Ghali, M. Elboujdaini, Corrosion Prevention and Protection: Practical Solutions (Wiley, New York, 2007)

15. M.A. Ameer, A.M. Fekry, A.A. Ghoneim, F.A. Attaby, Electrochemical corrosion inhibition of steel in alkaline chloride solution. Int. J. Electrochem. Sci. 5, 1847-1861 (2010)

16. A. Bhattacharya, P.M. Singh, Stress corrosion cracking of welded 2205 duplex stainless steel in sulfide-containing caustic solution. J. Fail. Anal. Prev. 7(5), 371-377 (2007)
17. S.A. Bradford, J.E. Bringas, Corrosion Control, vol. 115 (Van Nostrand Reinhold, New York, 1993)

18. B. Bozzini, F. Bogani, G. Giovannelli, S. Natali, G. Scarselli, M. Boniardi, Corrosion of stainless steel grades in $\mathrm{H}_{2} \mathrm{O} / \mathrm{KOH} 50 \%$ at $120^{\circ} \mathrm{C}$ : AISI304 austenitic and 2205 duplex. Mater. Corros. 64(11), 988-995 (2013)

19. A. Fattah-alhosseini, S. Vafaeian, Passivation behavior of a ferritic stainless steel in concentrated alkaline solutions. J. Mater. Res. Technol. 4(4), 423-428 (2015)

20. L. Freire, M.J. Carmezim, M.A. Ferreira, M.F. Montemor, The passive behaviour of AISI 316 in alkaline media and the effect of $\mathrm{pH}$ : a combined electrochemical and analytical study. Electrochim. Acta 55(21), 6174-6181 (2010)

21. L. Freire, M.J. Carmezim, M.G.S. Ferreira, M.F. Montemor, The electrochemical behaviour of stainless steel AISI 304 in alkaline solutions with different $\mathrm{pH}$ in the presence of chlorides. Electrochim. Acta 56(14), 5280-5289 (2011)

22. L. Peterman, R.A. Yeske, Thiosulphate effects on corrosion in kraft white liquor, in IPC Technical Paper Series, vol. 205, Appleton, WI, USA (1986)

23. F.A. Almuaili, S.A. McDonald, P.J. Withers, D.L. Engelberg, Application of a quasi in situ experimental approach to estimate 3 -D pitting corrosion kinetics in stainless steel. J. Electrochem. Soc. 163(13), C745-C751 (2016)

24. A.K. Mishra, D.W. Shoesmith, The activation/depassivation of nickel-chromium-molybdenum alloys: an oxyanion or a $\mathrm{pH}$ effect-Part II. Electrochim. Acta 102, 328-335 (2013)

25. J. Deakin, Z. Dong, B. Lynch, R.C. Newman, De-alloying of type 316 stainless steel in hot, concentrated sodium hydroxide solution. Corros. Sci. 46(9), 2117-2133 (2004)

26. B. Krawczyk, P. Cook, J. Hobbs, D. Engelberg, Corrosion behavior of cold rolled type $316 \mathrm{~L}$ stainless steel in $\mathrm{HCl}$ containing environment. Corrosion 73(11), 1347-1358 (2017)

27. I.-H. Lo, Y. Fu, Effect of electrolyte composition on the activeto-passive transition behavior of 2205 duplex stainless steel in $\mathrm{H}_{2} \mathrm{SO}_{4} / \mathrm{HCl}$ solutions. Corros. Sci. 48, 696-708 (2006)

28. P. Reccagni, L.H. Guilherme, Q. Luc, M.F. Gittos, D.L. Engelberg, Reduction of austenite-ferrite galvanic activity in the heataffected zone of a Gleeble-simulated grade 2205 duplex stainless steel weld. Corros. Sci. (2019). https://doi.org/10.1016/j. corsci.2019.108198

29. Jun-Seob Lee, Koji Fushimi, Takayuki Nakanishi, Yasuchika Hasegawa, Yong-Soo Park, Corrosion behaviour of ferrite and austenite phases on super duplex stainless steel in a modified green-death solution. Corros. Sci. 89, 111-117 (2014)

30. L. Troselius, in 11th International Pulp and Paper Industry Corrosion in the Pulp and Paper Industry, Charleston, South Carolina (2004)

31. D. Lachenal, Electrochemical behaviour of nickel(II) and Ni(IV) $\mathrm{N}, \mathrm{N}$-diethyldithiocarbamates. Synthesis of a nickel (IV) species. Inorg. Nucl. Chem. Lett. 11(2), 101-106 (1975)

32. G. Santarini, J.Y. Boos, Corrosion of austenitic stainless steels in hot concentrated aqueous $\mathrm{NaOH}$ solutions. Corros. Sci. 19(4), 261-281 (1979)

33. J.R. Davis (ed.), Corrosion: Understanding the Basics (ASM International, Geauga County, 2000)

34. C.M. Lampert, T.R. Omstead, P.C. Yu, Chemical and optical properties of electrochromic nickel oxide films. Sol. Energy Mater. 14(3-5), 161-174 (1986)

35. C. Zhang, F.R.F. Fan, A.J. Bard, Electrochemistry of oxygen in concentrated $\mathrm{NaOH}$ solutions: solubility, diffusion coefficients, and superoxide formation. J. Am. Chem. Soc. 131(1), 177-181 (2008)

36. E. Vito, P. Marcus, XPS study of passive films formed on molybdenum-implanted austenitic stainless steels. Surf. Interface Anal. 19(1-12), 403-408 (1992) 
37. S. Tardio, M.L. Abel, R.H. Carr, J.E. Castle, J.F. Watts, Comparative study of the native oxide on $316 \mathrm{~L}$ stainless steel by XPS and ToF-SIMS. J. Vac. Sci. Technol. A Vac. Surf. Films 33(5), 05E122 (2015)

38. M.C. Biesinger, B.P. Payne, A.P. Grosvenor, L.W. Lau, A.R. Gerson, R.S.C. Smart, Resolving surface chemical states in XPS analysis of first row transition metals, oxides and hydroxides: Cr, Mn, Fe, Co and Ni. Appl. Surf. Sci. 257(7), 2717-2730 (2011)
39. N.S. McIntyre, M.G. Cook, X-ray photoelectron studies on some oxides and hydroxides of cobalt, nickel, and copper. Anal. Chem. 47(13), 2208-2213 (1975)

40. L.H. Guilherme, P. Reccagni, A.V. Benedetti, C.S. Fugivara, D.L. Engelbergc, Corrosion assessment of ASME qualified welding procedures for grade 2101 lean duplex stainless steel. Corrosion (2019)

Publisher's Note Springer Nature remains neutral with regard to jurisdictional claims in published maps and institutional affiliations. 